\title{
SOCIAL MEDIA AND THE ACTIO INJURIARIUM IN SOUTH AFRICA - AN EXPLORATION OF NEW CHALLENGES IN THE ONLINE ERA
}

\section{$1 \quad$ Introduction}

The rapid rise in the use of social media networking sites in South Africa has posed new challenges to our courts. The law of defamation and privacy, which has long been considered well established, is now facing new demands on its boundaries because of the unique characteristics of social media in the online era.

This note will discuss and critique three recent cases individually, concerning issues arising from the use of Facebook (a social media website) and the approach of the courts in extending the traditional law to the new demands of social media interaction.

The aim of the note is to evaluate: the considerations which should apply to the granting of an interdict in respect of comments posted on Facebook, especially where alternative remedies are available; whether social media should be treated differently from electronic news media; how to establish ownership of a Facebook profile where such ownership is disputed; liability for anonymous defamatory posts on an individual's Facebook profile; whether an individual can be liable for defamatory posts not made by himself personally, but in which he has been tagged; whether comments posed as questions can be regarded as defamatory; and the role played by apologies in claims for damages in defamation.

The note concludes by discussing how South African courts have extended the traditional principles governing the actio injuriarium action in South African law - to the new challenges posed by the rise in popularity of social media networking sites.

\section{$2 \quad$ Heroldt $v$ Wills (2013 (2) SA 530 (GSJ))}

The applicant and respondent had been good friends for 15 years (Heroldt $v$ Wills supra 533 par 2) prior to the application. The applicant had assisted the respondent in starting her business, and the respondent had lent the applicant money when he experienced financial difficulties. Furthermore, the respondent had been appointed as the guardian of the applicant's children should the applicant and his wife both die simultaneously or be rendered incapable of looking after their minor children (Heroldt $v$ Wills supra 534 par $5)$. 
This close friendship soured when the applicant's wife left him and moved in with the respondent. The applicant and his wife are currently contesting a divorce action. The three minor children (girls aged 16 and 14 and a boy aged 12) resided with the applicant after the separation and the applicant paid for various expenses of the children. The applicant was an avid social networker (Heroldt $v$ Wills supra 533 par 3) and had accounts on both Facebook and Twitter. The applicant and the respondent were friends in the "real world" and in the virtual world on Facebook. The applicant, however, "unfriended" the respondent after his estranged wife moved in with her. The two minor female children, however, remained friends with the respondent on Facebook.

On 27 February 2012 the respondent posted an open letter to the applicant which she intended to be for "public consumption" (Heroldt $v$ Wills supra 533 par 2). This open letter included the following paragraph - which gave rise to the current action:

"I wonder too what happened to the person who I counted as a best friend for 15 years, and how this behaviour is justified. Remember I see the broken hearted faces of your girls every day. Should we blame the alcohol, the drugs, the church, or are they more reasons to not have to take responsibility for the consequences of your own behaviour? But mostly I wonder whether, when you look in the mirror in your drunken testosterone haze, do you still see a man?"

The applicant alleged that the Facebook posting represented him as a father who did not financially provide for his family, and as a father who would rather drink alcohol than look after his family - and/or as an individual with an alcohol- and drug-addiction problem (Heroldt $v$ Wills supra 534 par 6 ). He thus applied to the court for an order compelling the respondent to remove the offending post from Facebook, and an interdict restraining the respondent from posting any information relating to the applicant on Facebook or any other social media. In addition, he asked the court for an order to the effect that the respondent be jailed for a period of 30 days should she fail to comply with the order, and for an order that the Sheriff of the court be ordered and authorised to remove the offending post should the respondent fail to do so. The respondent denied any intention to defame and maintained that the post in question was intended to hold a mirror up to the applicant - to enable him to contemplate the paths he had chosen in his life.

Willis $\mathrm{J}$ in his judgment (Heroldt $v$ Wills supra 534 par 7) referred to our primordial common-law rights to privacy and freedom of speech which are enshrined in our Constitution. He then went on to state that the introduction of social media is creating unforeseen tension relating to these ancient rights. He further stated that it was the duty of the courts to develop the common law harmoniously in accordance with our Constitution (Heroldt $v$ Wills supra 534 par 8), and that due to the development of technological process in modern society and the resultant social changes, a high level of skill is required from the courts who have to respond appropriately to these changes. 
Willis $\mathrm{J}$ also pointed out the lacuna relating to social media in South African law. He stressed that he wished his judgment to be accessible to readers and proceeded to explore the functioning of Facebook lengthily as well as the various features offered by the site to safeguard users' privacy, before tangentially briefly exploring other social media sites such as Google, Twitter and Linkedln.

In my view the decision of Willis $\mathrm{J}$ to render an accessible judgment was a lamentable one as he was in the enviable position of rendering a judgment solidly based on extending the current legal principles to the demands of new technology - and chose instead to sacrifice solid, detailed legal analysis on the altar of reader understanding and accessibility. Judgments are utilised mainly by persons employed in the legal sphere. As such, these professionals are familiar with dissecting legal arguments and judgments. Accordingly, I submit that reader accessibility should not have been such an over-riding concern. In light of the lacuna in the law concerning social media in South Africa, Willis $\mathrm{J}$ would have done better service to our jurisprudence by rendering a judgment more solidly grounded in legal principles - thus contributing to the elimination of the lacuna in the law in the area involving interactions on social media platforms. Despite this criticism, Willis J's judgment does add to established principles - in that he extends them in order to cope with the new demands placed on them by social media.

Willis $\mathrm{J}$ then considered the linkage between the law of privacy and defamation in South Africa. He followed the ratio of the court in Jansen van Vuuren $v$ Kruger (1993 (4) A 842 (A)), which held that in order to determine whether an invasion of privacy is justified, one needs to determine whether a defence of justification in the law of defamation can be applied.

The only exploration on whether the offending post was defamatory is made in a few lines (Heroldt $v$ Wills supra 542 par 6), with Willis $\mathrm{J}$ blithely concluding that the post was defamatory before proceeding - briefly again to discover whether any justification could be provided for the post. In quick order he then concludes that the applicant cannot raise the defences of truth for the public benefit (as the information provided was not in the interest of the public) and fair comment (as he concluded that the respondent's conduct had been actuated by malice).

The court then went on to consider the requirements for an interdict as set out in Setlogelo v Setlogelo (1914 AD 221 227), and concluded that the applicant had both a right to his privacy and the right to protect his reputation. The difficulty with granting an interdict in this scenario arose because there was not an absence of similar protection by other remedies available to the applicant. It was argued that the applicant could simply have applied for damages instead of an interdict as if he had been defamed and was entitled to an action for damages. Alternatively he could have asked Facebook to remove the offending post. The respondent argued that due to these two alternatives being available to the applicant, this would negate the applicant's ability to apply for an interdict. 
Willis $\mathrm{J}$ stated that the common-law remedies for infringements of privacy need to be developed where infringements of privacy occur in the social media. He distinguished between social media and electronic media in that social media are part of electronic media - but not all electronic media are social media (Heroldt $v$ Wills supra 544 par 31). Both forms of media were not foreseeable when the Setlogelo judgment was handed down. In the modern age comments can be posted and removed almost instantaneously on both the electronic and social media - at minimal cost. This, he stated, was "qualitatively different" (Heroldt $v$ Wills supra 544 par 31) from the situation of newspapers in hard copy. It was thus imperative that the courts responded to the changing times.

Historically, South African courts have been very reluctant to interdict publication by the media, both due to the cost and technology involved in stopping or retracting hard copies of newspapers, and the social consequences which could occur due to the "chilling effect" of such court orders on freedom of expression by the media.

Willis $\mathrm{J}$ stated that, while news items of significant impact could feature on both social media and news media, this did not in fact render social media news media. The purpose behind Facebook is primarily the human inclination to be social, whereas the imperative purpose of the electronic media is to provide news. The social media is thus "qualitatively different" (Heroldt $v$ Wills supra 545 par 35 ) from the electronic media and as such:

"attitudes by the courts to the removal of items from the social media may be justifiably different in the case of the news media, even where the news media appear in electronic rather than print form" (Heroldt v Wills supra 545 par 35).

It is submitted that the position adopted by Willis $\mathrm{J}$ in this regard was a sound, practical one recognising the different roles played by the social and electronic media in an individual's life. Generally individuals do interact on Facebook in order to satisfy their social needs and would filter any news items found on the site through a more critical eye for truthfulness and possible bias than they would for similar items on electronic news media which they consult for purposes of obtaining information on news items which interest them. Thus his different treatment of social and electronic media is a pragmatic one.

The respondent contended that the applicant had other remedies available to him, other than an interdict - in that he could approach Facebook to have the offending post removed after having reported the abuse. The court responded that there was no evidence before it to be convinced that Facebook would have complied with a request for the removal of the post, and stated that if invasions of privacy are to be successfully restrained one should act against the wrongdoers themselves instead of the providers of the social media.

In regard to the respondent's second assertion that the proper claim of the applicant was not an application for an interdict but rather an action for damages, Willis $\mathrm{J}$ held that such an action would lead to "needless expense, drama, trauma and delay" (Heroldt v Wills supra 546 par 39). 
Willis $\mathrm{J}$ therefore granted the applicant's request for removal of the offending post from Facebook. He, however, refused to grant an interdict restraining the respondent from making any comments about the applicant on any social media, as he stated that there may be circumstances in the future in which the respondent may be able to justify publication about the applicant on social media. Willis $\mathrm{J}$ should be commended for this evenhanded approach as he has effectively rendered an order which both protects the applicant from any invasion of his rights to privacy or reputation, as well as protecting the rights of the respondent to freedom of speech - in that the removal of her offensive posting is a justifiable limitation of her right to freedom of speech, while any future comments are not immediately vetoed but rather can be scrutinised in the future circumstances. It is submitted that, should the court have granted the applicant's request to prohibit any further comments about him on Facebook the court would have been wielding its power as a sledgehammer to completely destroy the rights of freedom of speech of the respondent. By adopting the approach it did the court preserved both the applicant's right to protect his reputation as well as protecting the respondent's right to freedom of speech.

Willis $\mathrm{J}$ also refused the applicant's request that the respondent be jailed for 30 days in the event that she does not remove the offending post as ordered. He stated that it is "unseemly for the courts to wield their authority with a sledgehammer" (Heroldt $v$ Wills supra 546 par 41) and that there were other options available to the applicant should the respondent fail to comply with the court order. To my mind this is a very balanced pragmatic approach, in that Willis $\mathrm{J}$ has not overly penalised the respondent for a lapse in judgment - while ensuring that the applicant's rights are also protected.

Willis $\mathrm{J}$ also offered his doubts about the request of the applicant that the Sheriff of the Court be ordered and authorised to remove the offensive posting should the applicant fail to do so, as he did not believe that the Sheriff of Randburg had the expertise to remove the post. He thus made no order as to this request, but stated that the applicant could approach him again on this issue should future circumstances warrant this.

This case sounds the warning bell for users of social media who make offensive postings about others - in that they should remove such postings immediately upon the request of the parties offended. It would be rarely worth challenging the responsibility to remove offensive postings.

\section{$3 \quad$ Isparta v Richter 2013 (6) SA 529 (GNP)}

The plaintiff and the second defendant were previously married and had two children, a girl aged 6 and a boy aged 4 , during the marriage. At the time of the action, the plaintiff and the second defendant were divorced and both had remarried. The first defendant in this action was the new wife of the second defendant. Prior to this action the plaintiff and the second defendant were involved in discordant litigation over various issues arising from a settlement agreement entered into between them during the divorce proceedings. The two children born of the plaintiff and second defendant 
usually resided with the plaintiff. In addition, the plaintiff's new husband had a 16-year-old son who also resided with him, the plaintiff, and her children from her previous marriage.

On 13 April 2012 the first defendant posted various comments at different times of the day on her Facebook wall - in which she also tagged the second defendant. The plaintiff asserted that two particular postings made in the string of postings that day were defamatory and injured her reputation.

The first posting which the plaintiff alleged as being defamatory towards herself was made at $13 \mathrm{~h} 06$. The posting was an open letter to "Louise" (Isparta v Richter supra 532 par 13). (The plaintiff's first name was Louise.) The first defendant stated in this post that she knew that Louise would see the post as she implied that Louise regularly searched her posts for information on the activities of the first and second defendant. It went on to claim that the second defendant was happy that Louise found her activities so interesting and suggested that Louise get her facts right before she again made statements about things she knew nothing about - thereby embarrassing herself. The plaintiff claimed that the posting was defamatory in that it disparaged and belittled her (Isparta v Richter supra 534 par 19), as it alleged that she displayed an inordinate, alleged interest in the lives of the first and second defendants and that she was meddlesome and interfering (Isparta v Richter supra 537 par 33).

While the plaintiff's name was Louise, the posting did not refer to Louise's surname, and the first defendant had three "Facebook friends" who had the first name of Louise (Isparta $v$ Richter supra 535 par 21). The plaintiff, therefore, in accordance with the well settled principles of defamation, had to prove that the comment referred to her directly, or if it did not refer to her directly she needed to prove that the circumstances surrounding the post identified her to the reasonable reader of the post. As no surname was given the plaintiff had to prove that due to the circumstances surrounding the post the reasonable reader would associate the name "Louise" referred to in the offending post - with herself. The plaintiff contended that the reasonable reader would make this association. The readers of this post would be people who were Facebook friends of either the first and/or the second defendants, and she alleged that many of these readers were in fact aware of the disputes between herself and the second defendant. As such, they would associate the disparaging remarks directed at "Louise" as being made in respect of her.

The court agreed with the plaintiff's contentions and Hiemstra AJ held that "even though there might be more than one Louise ... in the circle of friends and acquaintances of the plaintiff and the defendants, everyone knew which Louise was being addressed. They did not need a surname to identify the plaintiff" (Isparta v Richter supra 535 par 21). Furthermore, while the posting did not "constitute serious defamation, publication thereof was gratuitous and with the intention to place the plaintiff in a bad light" (Isparta $v$ Richter supra 537 par 33). 
The second posting which the plaintiff claimed was defamatory was made later in the day at $16 \mathrm{~h} 38$. In this posting the first defendant again tagged the second defendant and asked parents what they would think of a person who let a stepson regularly bath a six-year-old stepsister, because it made their lives more convenient. This post did not refer to the plaintiff by name and the court held that in "isolation it cannot be said to refer to her" (Isparta $v$ Richter supra 536 par 27). However, Hiemstra AJ held that one cannot look at the posting in isolation and must consider it as forming part of an "exchange of messages" (Isparta v Richter supra 536 par 27) which had been posted on the defendant's Facebook wall within a short period of time. He declined to follow the view adopted in Geyser v Pont (1968 (4) SA 67 (W)) - that where one was dealing with a series of articles one should consider each article separately. Hiemstra AJ opined that this dictum is often quoted out of context (Isparta $v$ Richter supra 536 par 28) as the court in that case held that previous articles could in fact be used in interpreting subsequent articles. Despite this clarification of the dictum, Hiemstra AJ held that Geyser's judgment was one based on the facts of that case - which were very different from the facts before him in the current case. He went on to state that the reasonable Facebook reader would have understood the second posting as referring to the plaintiff, even though she was not named in it - in light of the string of previous postings made by the first defendant within a short period of time.

The defendants also contended that the second posting could not be defamatory of the first plaintiff as the second posting took the form of a question posed to readers - and not a statement. The court therefore had to determine whether the posing of a question could be considered defamation. The court held that, while grammatically the post took the form of a question, embedded in this question was the statement that the plaintiff permitted her 16 year-old stepson to bathe her 6-year-old daughter each evening as this was expedient for her (Isparta $v$ Richter supra 537 par 31). Hiemstra AJ, held that the posting was not a question per se, as it did not ask whether the plaintiff allowed such an action, but rather implied that she condoned such an action and then asked what other parents thought of such activities. Hiemstra AJ, held that the posting was reprehensible as it suggested that the plaintiff supported and allowed paedophilia and sexual deviations. The damage to the plaintiff's reputation was further compounded by the addition of sarcastic and unpleasant comments made by the readers of the post.

The court concluded that both postings made by the first defendant were defamatory. The court then had to consider the position of the second defendant. It held that, while the second defendant was not the author of the posts, he had knowledge of the posts and allowed his name to be linked with the name of the first defendant - and as such was just as liable for the postings made by the first defendant.

I submit that the court's ruling in regard to the second defendant is just and apt. Facebook is a user-friendly medium and if the second defendant disagreed with the postings or wished not to endorse them, he could have easily "untagged" himself from the posts or made a comment on the posts 
distancing himself from them. By allowing himself to remain tagged in the posts he implicitly endorsed his support for the posts and bolstered their alleged veracity - thereby compounding any damage suffered by the plaintiff. As such he should be jointly liable for the damages suffered by the plaintiff.

I would, however, caution that future courts facing the issue of having to determine the liability of defendants who have been tagged in a post should not merely blindly follow Hiemstra AJ's ruling. It is submitted that the second defendant in this case was aware of the posts made and his tagging in such posts and by choosing to not untag himself implicitly endorsed the posting. His implicit endorsement of such post would lend credence to the views expressed by the first defendant as he had been married to the plaintiff in the past, and thus persons who read the post would be more likely to believe the veracity of the postings due to such implicit endorsement. However it does not necessarily follow that a future defendant who was simply tagged in a post which he or she has no knowledge of should also be held similarly liable. As such future courts must judge a potential defendant's liability in terms of the individual circumstances prevailing in that case in order to ensure that a just decision is reached.

Hiemstra AJ obiter opined that "an apology to the plaintiff, or a retraction in writing, in the same forum that the offending statements had been made, also clears the name of the plaintiff" (Isparta v Richter supra 538-539 par 41). However, since neither of the defendants had apologised to the plaintiff and appeared to still believe that they were permitted to publish any statement they wished on Facebook - the court awarded damages of R40 000 to the plaintiff. Both defendants were found to be jointly and severally liable for that sum.

Hiemstra AJ adopted a very level-headed approach in his judgment and extended the protection of the traditional laws relating to defamation to an applicant who sought protection from defamatory comments made in the online world. He answered questions which are bound to appear constantly in the future. These include the liability assumed by persons who have not made defamatory comments per se, but who have merely been tagged in them, and also the role that apologies play in defamatory comments made on social media. As such, Hiemstra AJ has helped to contribute to the framework of laws which now need to be extended to cope with the demands placed on them by the exponential growth of social media. In addition, by stressing the importance of an apology tendered to the wronged person, any future defendant facing a similar action would do well to tender an apology as soon as possible, via the same media in which the offending comment was made, in order to avoid the awarding of damages against himself or her. 


\section{Dutch Reformed Church Vergesig v Sooknunan 2012 (6) SA 201 (GSJ)}

The first applicant in this matter was a Christian religious organisation which was the owner of church premises leased to the respondent. The second applicant was Hendrik Abel van Rooyen (hereinafter "Van Rooyen") - who is an ordained minister of the applicant Church, as well as chairman of its Church Council. The respondent, Sooknunan (hereinafter "S"), was the founder and the head of the Glory Divine World Ministries (hereinafter "GDWM").

The applicants sought to interdict the respondent from making defamatory comments - both in the press and on Facebook - as well as from publishing private information relating to the second applicant and his attorneys.

This case raised important issues relating to the manner in which social media such as Facebook can be used by members of the public, and the legal implications flowing from such use (Dutch Reformed Church Vergesig $v$ Sooknunan supra 203 par 3). In addition, it examines the juxtaposition between conflicting rights: the right to freedom of expression, the right to reputation and the right to religion, while also simultaneously exploring the appropriate use of demagogic language and incitement while promoting a cause.

The first applicant had historically utilised the church premises for its religious activities. In 2000/2001 the first applicant resolved to permit another Christian organisation to utilise the church premises for religious services after its own religious services had been completed for the day. As such, the GDWM began utilising the church premises for its own services. Unfortunately for the applicant, as the years passed by, its membership declined drastically while the membership of the GDWM increased until it numbered about 1000 congregants. In 2010 the applicants came to a decision to sell the church premises and offered $S$ the opportunity to purchase the premises. The applicants and the respondent could not, however, reach an agreement on the purchase of the premises. The Council of the first applicant thereafter offered to lease the premises to the respondent and GDWM, until the premises was sold. In February 2011 GDWM then began occupying the premises as a tenant. In October 2011 the first applicant notified the respondent and GDWM that the premises had in fact been sold to a Muslim religious organisation and gave them notice to vacate the property. The respondent did not react well to this notice and immediately replaced the locks on the doors - thereby preventing the first applicant from accessing the property. The respondent and GDWM then began a public crusade to persuade the first applicant from finalising the sale of the premises.

The second applicant alleged that the respondent created a Facebook profile in the name of GDWM and utilised this profile to pursue "a vicious vendetta against me and the first applicant" (Dutch Reformed Church Vergesig v Sooknunan supra 205 par 12). He further claimed that comments 
were made on the Facebook wall with the purpose of inciting the public to act against both the first applicant and himself personally. He believed that these incendiary comments placed his life in personal jeopardy, as "some members of the public are extremely radical" (Dutch Reformed Church Vergesig $v$ Sooknunan supra 205 par 13). In addition, a post on this Facebook wall revealed the contact phone number and email address of both the second applicant and his attorney, and the second applicant stated that he had already received numerous threatening phone calls and emails.

$S$ did not admit to being the author of all the incendiary comments, but, in regard to the ones to which he admitted authorship he claimed the defence of fair and reasonable comment. Satchwell $\mathrm{J}$ held that the court must not only consider this defence but also the constitutional protection afforded to freedom of expression in debate. This was especially important in a matter such as this one which involved religious, racial and class undertones. However, these factors do not lead to an unfettered right to express all thoughts and viewpoints and is still limited to expression of views and thoughts which could be considered reasonable and justifiable in a democratic society based upon human dignity, equality and freedom (Dutch Reformed Church Vergesig v Sooknunan supra 206 par 21). In testing the bounds of freedom of expression the court must consider the:

"issues involved, the context within which the debate takes place, the protagonists to the dispute or disagreement, the language used as well as the content of that which is said, written and published and about whom it is published" (Dutch Reformed Church Vergesig v Sooknunan supra 207 par 23).

$S$ denied that he was the creator of the Facebook profile, however, Satchwell $\mathrm{J}$ swiftly and correctly swept aside this denial stating that "if it looks like a duck, quacks like a duck and waddles like a duck, then it probably is a duck" (Dutch Reformed Church Vergesig $v$ Sooknunan supra 209 par 34). She held that the profile name was GDWM and the only issues and comments on the page revolved around GDWM issues. As such, it was highly probable that it was a GDWM page, and any denial by $S$ of this was implausible. She gave many reasons for this finding. Firstly, the profile name was distinctive and unusual and could logically be said to refer to GDWM in this matter - as the content of the Facebook page referred almost exclusively to the dispute between $S$ and the applicants. Secondly, the Facebook profile was regularly updated with information keeping its readers abreast of developments about the issue between the applicants and the respondent. Thirdly, many comments and postings on the profile page originated from $S$ - who gave his address as GDWM's website. Satchwell J further rejected S's contention that the Facebook page was not that of GDWM, but rather of a support group of GDWM. As $S$ was the founder and head of GDWM and utilised a very slick and edifying website to provide details of church activities and his own qualifications, as well as for requesting funds from readers, it was not plausible that he would permit strangers to interfere with the careful branding of his church which he had so painstakingly created (Dutch Reformed Church Vergesig $v$ Sooknunan supra 210 par 38). 
If a stranger had purported to interfere with the branding and image of GDWM, S would definitely have disputed his/her right to do so, and would have voiced opinions on behalf of himself and GDWM. He would not have allowed others to contribute and would not, himself, have further contributed to a Facebook page over which he had no control. Thus the court found that $S$ was the owner of the Facebook page on which the incendiary comments had been posted.

The approach used by Satchwell $J$ in determining ownership of a Facebook profile in cases of disputed ownership is a practical one. Satchwell $\mathrm{J}$ should be commended for her insightful and thorough analysis of the surrounding factors and her use of these in determining ownership of the disputed profile.

Another issue on Facebook is that posters can post anonymously. The court dealt with this issue by holding that the creator of a Facebook profile is responsible for posts made on the profile as his or her role is akin to that of a publisher who has made a forum available for the posting of unlawful content. As such, S was responsible for the content of comments posted on his Facebook wall, and had a duty to remove posts if the content of such was unlawful.

The applicants were further alarmed by the incendiary words in the posts. These included words such as "holy war", "this battle", "to die", "fire", "sold him for 30 pieces of silver", "the NG Kerk should be ashamed of themselves", and "how can a Christian sell the house of God" (Dutch Reformed Church Vergesig v Sooknunan supra 214 par 52).

Satchwell $\mathrm{J}$ held that, in evaluating the phrases used, one must look to the user of the language as interactions between people reflects the characteristics of the users of language. In a dispute between two religious organisations it is to expected that such dispute will be aired using the language of that religion - in this situation being that of the King James Bible. She stated that such language is:

"frequently allegorical and often metaphorical. What is said or written is designed to catch the ear and the mind and the heart of the listener, reader or singer, the congregant, believer or non believer ... [it is also] aggressive and warlike or militant" (Dutch Reformed Church Vergesig v Sooknunan supra 215 par 62 and 63).

She thus postulated that it was not unexpected that the parties concerned - particularly the respondent and GDWM - would have used the language of the King James Bible (which is as stated by Satchwell above "frequently allegorical or metaphorical" as well as "aggressive" and "militant"), and, as such, the language used was not meant to encourage violence nor did it mean to incite religious hatred. This conclusion is a pragmatic one, as in situations of intense discord robust language is often utilised frequently without any intent to defame.

Satchwell $J$ then went on to deal with the issue of the Facebook wall making Van Rooyen and his attorney's email address public. As a result of the publication of the email addresses on the Facebook wall, both Van 
Rooyen and his attorney had received threatening phone calls and emails. S argued that there should be no culpability attached to the publication of the email addresses on the Facebook wall, as this information was already in the public domain. Satchwell J disagreed with this assertion - stating that if this were true then there would have been no need for $S$ to place this information on the page. The only purpose behind this action was to incite and allow readers of the page to contact Van Rooyen and his attorney. She stated that this was a gross invasion of their right to privacy, as by exposing their personal contact details it imperilled their right to communicate routinely with others, and, furthermore, it subjected them to unwelcome and unnecessary emails. She stated further that individuals only have the right to make their email addresses public (Dutch Reformed Church Vergesig $v$ Sooknunan supra 217 par 78.

Satchwell $J$ then went on to specifically canvass every individual statement made by the respondents. She found none of them to be inflammatory or made with the intent of inciting violence. She did find some to be injurious, however, and in regard to those he interdicted the respondents from persisting with those statements. She also ordered the respondents to remove contact information of Van Rooyen and his attorney from the Facebook pages, and to refrain from disclosing any other private information of those individuals in the future.

Satchwell $J$ should be applauded for a very well-reasoned and logical judgment based on solid legal principles. She effectively utilised existing legal principles and seamlessly fused them with the new demands placed on old laws - flowing from developments created by the advent of social media. Satchwell $\mathrm{J}$, in effect, created a synergistic, new base to tackle modern issues. Her approach is pragmatic and future judgments concerning social media would do well to emulate her reasoning. It is submitted that as the use of social media is at an embryonic stage in South Africa our courts will be faced with many new issues which we have not encountered before. It is opined that if future courts tackle these new issues in a pragmatic fashion (as displayed by Satchwell $\mathrm{J}$ in this judgment) which is alive to the ways in which individuals utilise and view social media then the existing law can be easily adapted to the new demands placed on them by wider use of social media.

\section{$5 \quad$ Conclusion}

It can be seen that our courts have not been afraid to extend the traditional principles governing the actio injuriarium action in South African law to the new challenges posed by the rise in popularity of social media networking sites. They have recognised that the increase in online interactions means that the law must be adapted to deal with situations which arise from the unique characteristics of social media.

The judgments of the courts above show that they have determined that social media should not be treated in the same manner as the electronic and paper-news media - as the two are very distinct concepts. As such, an 
applicant should be allowed to apply for an interdict against a social media website - even when other remedies are available to them. This is in stark contrast to the treatment of the news media in general, where courts are reluctant to grant interdicts if other remedies are available.

We have also seen that the above courts recognise that the best approach to protect victims from infringements on social media is to allow them to approach the wrongdoers themselves for redress, instead of directing their actions towards the providers of social media websites. This approach is pragmatic, as approaching providers who are often located in foreign countries, would be extremely time consuming - thus exponentially increasing the damage suffered by the victim - and would also be extremely expensive. Allowing a victim to take action directly against the wrongdoer is a reasonable and realistic solution.

In addition, the judgments in this note demonstrate that our courts will adopt a common-sense approach when attempting to resolve disputes relating to the ownership of Facebook profiles. This flexible approach is highly commendable.

Our courts have also sounded a clarion warning bell to social media users, in that these users must learn to accept responsibility for their online actions. Users will not be able to hide behind spurious phrasing of defamatory remarks as questions instead of statements, and while the court will make allowances for inflammatory language used during emotionally charged dialogue, this concession is not an unlimited one, as the court will still seek to protect the rights of those at whom the comments are directed. Additionally, users who find themselves tagged in defamatory posts should untag themselves as quickly as possible from them, lest they find themselves also liable for the content of a defamatory post made by another person.

One should also not underestimate the value of an apology relating to an initial defamatory comment made utilising the same social media avenue. This is because such an apology may be regarded by a court as being a complete vindication of any slur on a complainant's character.

The courts in the above three judgments have shown that they are willing to adopt a flexible approach on an ad hoc basis, and extend the traditional principles of the actio injuriarium to cope with the new challenges posed by contemporary online social media. It is submitted that this approach is commendable, and it bodes well for future judicial matters involving the social media in South Africa 